\title{
Note
}

\section{Abolishing Coercion: The Jurisprudence of American Foreign Policy in the 1920's}

\author{
Jonathan Zasloff
}

Recent research has revised our view of American foreign policy during the 1920's. Historians now see American policymakers of that era not as naive isolationists, but as realistic appraisers of the nation's interests. They argue that the United States used its power to create an "informal" empire in which Washington dictated the rules of the global economy through intense involvement in international economic affairs. ${ }^{1}$ Thus, the United States could expand economically without assuming the burdens of global leadership.

But while these historians have demonstrated how policymakers perceived America's global interests, they have neglected those policymakers' conception of the global order. It is one thing to determine that the nation's primary interest lies in economic expansion; it is quite another to determine how the international system can remain stable so that expansion can occur. U.S. leaders rejected traditional prescriptions for a balance of power system, believing that such a system had led to disaster in 1914. Yet they could not rely on international economic growth alone, for World War I began after nearly two decades of global economic expansion. What, then, did American policymakers believe would foster international stability?

1. For good examples of this interpretation, see FRANK COSTIGLIOLA, AWKWARD DOMINION (1984); EMILY S. ROSENBERG, SPREADING THE AMERICAN DREAM (1982). The new interpretation derives its main assumptions from the work of William Appleman Williams. See, e.g., William Appleman Williams, The Legend of Isolationism in the 1920's, 17 SCI. \& SoC'Y 1 (1954). 
One answer is that policymakers looked to international law for stability. This is plausible, for lawyers dominated U.S. diplomacy during the first half of this century. ${ }^{2}$ Such a thesis, though, immediately raises questions. How did policymakers think that law would be enforced? And how could law pacify a world filled with conflict?

This Note argues that lawyers influential in foreign policy during the 1920 's believed (wrongly, as it turned out) that the legal arrangements they crafted could, in effect, enforce themselves. Force would not be needed to support international agreements because nations would have powerful incentives to follow them. This Note suggests, moreover, that the belief in law's capacity to police world affairs was rooted in the prevailing legal ideology of the late nineteenth and early twentieth centuries, which this Note calls "scientific legal culture." Originating in response to domestic crises, the scientific legal culture constituted a set of assumptions, beliefs, and normative commitments that, when taken together, justified the conclusion that law could have effect without resort to force. Lawyers believed that law could achieve social control not because it was backed by coercive state sanctions, but because it represented the common interest of all in society. Since legal structures enabled these values to be applied apolitically, it was in everyone's interest to follow the law. The rudiments of social order were enforced not by the policeman, but by the threat of isolation for those who flouted agreed-upon rules. Fear of losing the cooperation of others restrained those tempted to break legal agreements. Many lawyers believed, following similar reasoning, that law could emerge as the principal guarantor of international stability. In short, the gap in the American foreign policy literature-an explanation of how U.S. statesmen expected to maintain global order without committing troops-can be partially filled by the literature of American jurisprudence.

To understand America's global role in the 1920's, this Note focuses on two lawyers-Charles Evans Hughes and Elihu Root. Hughes served as Secretary of State from 1921 to 1925 and was the chief influence at the State Department throughout the decade. Root had completed a distinguished public career by the time of the GOP's return to power in 1921, but as the party's eminence grise and founder of the eastern foreign policy "establishment," his ideas underpinned Republican policy throughout the period.

Part $I$ of this Note describes three central facets of the scientific legal culture, which dominated American legal thought from 1877 to 1920. During this period, Root, Hughes, and other G.O.P. leaders acquired their critical ideological assumptions. Part II suggests how the assumptions behind this legal

2. For instance, from 1905 to the beginning of the Second World War, nine men served as Secretary of State. Eight (Elihu Root, Philander Knox, Robert Lansing, Bainbridge Colby, Charles Evans Hughes, Frank Kellogg, Henry Stimson, Cordell Hull) were lawyers; only one-William Jennings Bryan (19131915) - was not. By contrast, during the same period, nine men served as British Foreign Secretary. Only one-Sir John Simon (1931-1935)-had an extensive legal background. 
culture manifested themselves in foreign policy. Part III shows how these assumptions shaped Root's vision of international order, and how he applied this vision in the fight over the Versailles Treaty of 1919. Part IV examines the legal culture's influence on Hughes, and discusses his most significant diplomatic triumph: the Washington Conference of 1921-22.

\section{AMERICAN LEGAL CULTURE, 1877-1920}

The leading historian of the period has referred to the years between 1877 and 1920 as "The Search for Order" 3 and has observed that by the 1890's many Americans thought that the nation "would either disintegrate or polarize." Many Americans, however, rejected the idea that society had become a permanent power struggle between groups. Striving toward the ideal of consensus, they saw unity as an achievable goal. ${ }^{5}$ As early as the 1870 's, this camp, usually identified as the "middle class" by historians, ${ }^{6}$ sought to transcend the divisions that appeared to be tearing the country apart. Lawyers, especially the elite bar, formed a key part of this diverse group, ${ }^{7}$ and developed their own ideology, which I shall call the "scientific legal culture." The scientific legal culture reflected a variety of sometimes conflicting intellectual sources but achieved remarkable coherence in seeking to demonstrate that society was not inherently conflictual, and that the apparent

3. See ROBERT WIEBE, THE SEARCH FOR ORDER: 1877-1920 (1967) [hereinafter WIEBE, SEARCH].

4. Id. at 301. The rise of organized labor seemed to threaten stability, as did growing conflict between agrarian and urban interests. See RICHARD HOFSTADTER, THE AGE OF REFORM 4 (1955) These conflicts, combined with the influx of immigrants, appeared to endanger the American way of life. See RICHARD LEOPOLD, ELIHU ROOT AND THE CONSERVATIVE TRADITION 19-20 (1954).

5. See Robert Dallek, The AMerican StYle of Foreign POLICY 26-27, 32, 99-100 (1983) (Americans strove for domestic unity and consensus as central social goal).

6. Wiebe astutely points out, though, that "[i]n part, the new middle class was a class only by courtesy of the historian's afterthought" because it "cover[ed] too wide a range to form a tightly knit group. WIEBE, SEARCH, supra note 3 , at 112 .

7. See id. The search for consensus reflected a refusal to rely upon the other method of maintaining social order, namely, state coercion. A powerful state, of course, can achieve social order by favoring some groups over others, and using its coercive apparatus to prevent some groups from disturbing the newlycreated order. Stephen Skowronek has observed that American political culture at the turn of the century was unique because Americans had no "sense of the state," which he defines as the "sense of an organization of coercive power operating beyond our immediate control and intruding into all aspects of our lives." STEPHEN SKOWRONEK, BUILDING A NEW AMERICAN STATE 3 (1982). Skowronek contrasts this condition with the present, in which a "sense of the state' pervades contemporary American politics." Id.

8. For a discussion of the political culture that corresponded to the lawyers' efforts, see ROBERT H. WIEBE, BUSINESSMEN AND REFORM 179-205 (1962) [hereinafter WIEBE, BuSINESSMEN]. Wiebe notes:

The social theory of the business community resembled in a general way the views of comfortable Americans everywhere. Its major tenets-a restricted definition of the people, a belief in a leadership elite, a denial of classes, and a faith in individualism-all belonged to the standard philosophy of the early twentieth century.

Id. at 204. It should be added that the tenets of what should be called the "business culture" also served as hallmarks of the late nineteenth century. See Michael Les Benedict, Laissez-Faire and Liberty: A ReEvaluation of the Meaning and Origins of Laissez-Faire Constitutionalism, 3 LAW \& HIST. REV. 293 (1985) (arguing that antipathy to redistributive "class legislation" and concern for equal individual liberty formed core of laissez-faire ideology). 
social cleavages of the time were, in fact, unnecessary. ${ }^{9}$ These diverse intellectual origins created an ideology stressing three basic beliefs: the underlying mutuality of social interests, the separation of law and politics, and the law's ability to facilitate cooperation in areas of apparent conflict.

\section{A. The Mutuality of Interests}

The scientific legal culture took it as axiomatic that unified community sentiment created law. Joseph Beale, "the most self-consciously philosophical exponent" of late nineteenth-century legal theory, ${ }^{10}$ argued that the law's power to constrain individuals originated not in state sanctions but in custom generated by social consensus. "To make law really law," he asserted, "you have got to have behind it justice - the custom of regarding things as just-and this custom . . . is based on ... the customary morality of the body of the people ... . [T] his . . . is the fundamental of the law."ll

9. As stated above, the intellectual sources of the scientific legal culture were varied. It originated in the thought of Christopher Columbus Langdell and other important jurisprudes at Harvard Law School. Their thought, often known as "classical orthodoxy," see Thomas C. Grey, Langdell's Orthodoxy, $45 \mathrm{U}$. PITT. L. REv. 1, 2 (1983), came to dominate both the legal profession and the legal academy, and "erected a vast discursive structure that came to dominate legal education and to greatly influence the practical work of lawyers and judges." Id. For classical orthodoxy's influence on the legal profession, see Robert W. Gordon, Legal Thought and Legal Practice in the Age of American Enterprise, 1870-1920, in PROFESSIONS AND PROFESSIONAL IDEOLOGIES IN AMERICA 70, 88-94 (Gerald Geison ed., 1983) (detailing ideology and practice of late nineteenth-century legal science); for its influence on the legal academy, see ROBERT STEVENS, LAW SCHOOL 3-91 (1983). In addition, the scientific legal culture rested in large part on the historical jurisprudence of James Coolidge Carter, which according to Professor Horwitz "represents in a clear and unsubtle manner the intellectual paradigm for virtually all orthodox late nineteenth-century legal theory." MorTON J. HoRwitZ, THE TRANSFORMaTION OF AMERICAN LAW, 1870-1960, at 122 (1991). Orthodoxy's emphasis upon private law, however, meant that the scientific legal culture also took inspiration from theories of administration and economics in the public law sphere, most notably laissezfaire ideology and the type of conservative "business progressivism" exemplified by such social movements as the National Civic Federation. See Grey, supra, at 35 (noting that orthodox scholars' "natural political orientation ... was to the Mugwumps, and later to the right wing of the Progressive movement").

According to James Weinstein,

The National Civic Federation stood in opposition to what it considered its twin enemies: the socialists and radicals among workers and middle class reformers, and the "anarchists" among the businessmen [who opposed labor organization in every form] . . . Before the First World War the Civic Federation was the most important single organization of the socially conscious big businessmen and their academic and political theorists.

JAMES Weinstein, The CoRporate Ideal in The Liberal STATE: 1900-1918, at 6 (1968). Weinstein notes that lawyers-particularly corporation lawyers such as Root and Hughes-were important members of the NCF. Id. at 7. Thus, the NCF represented the "right wing of the Progressive movement."

10. Grey, supra note 9, at 29.

11. Warren J. Samuels, Joseph Henry Beale's Lectures on Jurisprudence, 1909, 29 U. MIAMI L. REV. 260, 291 (1975) (quoting Beale). This basic consensus served as the engine for legal development. Ames argued that law grew much like a human being did, from the "unmoral" principles of early law and children's ethics to more mature principles reflective of modern society. See JAMES BARR AMES, Law and Morals, in LECTURES ON LEGAL HISTORY 439 (1913).

Because demonstrating consensus was so critical, custom assumed a primary role in the scientific legal culture's view of legal origins. New York lawyer James Coolidge Carter, for instance, argued that law is not a command at all ... it is not the dictate of Force but an emanation from Order ... it is that form of conduct which social action necessarily exhibits, something which men can neither enact nor repeal, and which advances and becomes perfect pari passu with the advance 
When communities created laws for themselves, they gave birth to government. But such a government was not coercive. Instead, argued Beale, " $[t]$ he general social organization becomes ... upon its coexistence with law, what is called a state. ... The state, then, is the representative of the social interest." 12 Beale could speak of the state representing a single "social interest" because he shared scientific legal culture's faith in the fundamental mutuality of interests. ${ }^{13}$ Professor Gordon notes that the prevailing ideology held that "[l]awyers could help clients pursue their particular interests within a general framework ... that harmonized that interest with the whole."14 Such a view of law answered the ideological needs of those Americans who sought consensus because it held out the possibility of creating an ordered civil society free from coercion. ${ }^{15}$ If there were any social struggle, it would be cured through the creation and refinement of legal instruments that reflected consensual values and harmonized interests. ${ }^{16}$

and improvement of society.

JAMES COOLIDGE CARTER, LAW: ITS ORIGIN, GROWTH, AND FUNCTION 345 (1907). Such an analysis suited the purposes of the scientific legal culture perfectly: if laws had existed from time immemorial, and laws reflected custom followed by all members of society, then it followed that consensus was robust. Custom "represented a Rorschach blot onto which conservative social thinkers could project their fantasies of a naturally harmonious society free from the twin dangers of anarchy and coercion, yet capable of organic change and growth." HoRWITZ, supra note 9, at 123.

12. JoSEPH H. BEALE, A TREATISE ON THE CONFLICT OF LAWS 59 (2d ed. 1935) (emphasis added).

13. One sign of the scientific legal culture's antipathy toward even the idea of social conflict is found in the academic community's reaction to Arthur F. Bentley's pathbreaking 1908 work, The Process of Government. In that work, Bentley posited that the essential fact of politics was the conflict between various groups for access to wealth and power, a thesis which anticipated the pluralist school of political science that emerged in the 1950's. But instead of being recognized as visionary, Bentley was either dismissed or ignored. A typical reaction was that of James W. Gamer in the American Political Science Review, who in an untitled one-paragraph review commented that "a hasty reading of some of these chapters fails to impress the reviewer with their value as a contribution to the literature." 2 AM. POL. SCI. REV. 457 (1907). Two historians of political science observe that "[s]o far as his contemporaries were concerned, Bentley might never have existed ...." AlbERT SOMIT \& JOSEPH TANNENHAUS, THE DEVELOPMENT OF AMERICAN POLITICAL SCIENCE 68 (1967).

14. Robert W. Gordon, "The Ideal and the Actual in the Law": Fantasies and Practices of New York City Lawyers, 1870-19J0, in THE NEW HIGH PRIESTS: LAWYERS IN POST-CIVIL WAR AMERICA 51, 57 (Gerald W. Gawalt ed., 1984).

15. Many legal doctrines revolved around the need to make the law seem consensual and non-coercive. Orthodox legal theory held that in personam jurisdiction.could not be exercised upon an out-of-state defendant without his consent. See Pennoyer v. Neff, 95 U.S. 714 (1877). The problem was that when injured consumers or workers wanted to sue a corporation, which the law deemed an artificial "person," it was difficult to tell where that person "was," except to use its principal place of business or state of incorporation. But these might be far away from where the plaintiff was and where the injury occurred. Instead of abandoning the fiction of "consent," courts approved state statutes that required foreign corporations to appoint a local agent for service of process and declared that a state official would be so deemed if they did not. Since these corporations had "appointed" the state official, they had "consented" to being sued in local courts, and thus no coercion had taken place. See, e.g., Smolik v. Philadelphia \& Reading Coal \& Iron Co., 222 F. 148 (S.D.N.Y. 1915), approved in Pennsylvania Fire Ins. Co. v. Gold Issue Mining and Milling Co., 243 U.S. 93, 95 (1917).

16. See Gordon, supra note 9, at 93. 


\section{B. Law Versus Politics}

If social consensus created law, then why was there so much seeming conflict? To most late nineteenth-century thinkers, the difficulty lay in the perversion of politics by special interests and corrupt influence-peddlers. Essentially, people were cheating on the very system even though it was in their interest to support that system. Political machines, labor bosses, and corporate plutocrats had subverted governmental institutions. ${ }^{7}$ Legal thinkers, however, could discover social organizing principles based not upon corrupt politics, but upon value-neutral science. If laws were inspired by science rather than poisoned by politics, they could eliminate social struggle because they would be fair and consequently in everyone's interest to follow.

Thus, the scientific legal culture set as its central task the discovery of netural and scientific rules and procedures removed from politics. Langdell was the most outstanding exponent of this approach, but the goal of depoliticizing law dominated all of legal thought. ${ }^{18}$ The central method was to find the few general and abstract (and hence apolitical) principles underlying a field of legal thought by examining cases. ${ }^{19}$ Then, reason would enable judges to apply these principles to specific cases uncontroversially. ${ }^{20}$ According to the scientific legal culture, rationally compelling reasoning dictated all outcomes. $^{21}$

17. In the late nineteenth century, the "Mugwumps"-a group of high-minded professionals that included Harvard Law School Dean James Barr Ames-maintained that a combination of civil service reform and cooperation with "responsible" immigrant leaders could solve social conflict. See generally GEOFFREY BLODGETT, THE GENTLE REFORMERS: MASSACHUSETTS DEMOCRATS IN THE CLEVELAND ERA (1966) and $i d$. at 200-02, 282-83. In the early twentieth century, conservative progressives believed that impartial professionalism could destroy comuption and prevent the breakdown of the naturally harmonious society. Hughes stood as a prominent exponent of these beliefs. See Hughes' inaugural address as Governor of New York, 1907, reprinted in THE AutobiographiCAL Notes of Charles EVANS Hughes 134-35 (David J. Danelski \& Joseph S. Tulchin eds., 1973) (impartial administration "shall disarm reckless and selfish agitators and take from the enemies of our peace their vantage ground of attack"). Root, too, had a hard time believing that even revolutionary upheavals had anything to do with conflicts between social groups; instead, he contended, they "are ordinarily dictated by purely personal motives [and] involve no question of principle." Letter from Root to Henry L. Stimson (May 28, 1908) (Henry L. Stimson Papers, Sterling Memorial Library, Yale University) [hereinafter Stimson Papers].

18. See HoRwITZ, supra note 9, at 27. For instance, the idea arose of a unified law of "torts," centered upon the concepts of "negligence" and "fault." Id. at 13.

19. The classic formulator was, of course, Langdell. See Christopher COLUMBUS LANGDELL, A SElection of Cases on the Law OF CONTRACTS 20-21 (2d ed. 1879); see also GRANT Gilmore, The DEATH OF CONTRACT 67 (1974).

20. Cf. BEALE, supra note 12, at 48 (arguing that common law "was systematic; that is, it consisted of a system of thought based upon principles which covered every possible occurrence. Every human act was either permitted or forbidden; every act either changed or left unchanged existing rights").

21. See Grey, supra note 9, at 11. Similarly, classical orthodox historical writings reflected the belief that reason shaped past events. Logic, not the struggle for power, explained history. In his treatise on equity, Langdell argued that equitable jurisdiction arose because "[s]ometimes it would happen that a case would be presented to which no existing writ was adapted" even though the case "demanded a remedy of some kind" and "the king's judges, from the nature of their procedure, could either afford no remedy, or only an inadequate one.... It was in this way that the jurisdiction in equity arose." CHRISTOPHER COlUMbus LANGDell, A SUMMARY OF EQUTTY Pleading, at xix-xx (1877). Completely missing from Langdell's account were the fierce political battles that surrounded the equity courts, which were viewed 
Formalism $^{22}$ thus became the dominant mode of legal discourse. ${ }^{23}$ Judges protested that they were not policymakers but impartial interpreters of neutral legal principles. ${ }^{24}$ The Supreme Court saw neutrality as the central virtue of principled adjudication. The Court struck down social and economic legislation not because it mandated government involvement in the economy, but because it was "class legislation," that is, it redistributed wealth from one group to another and consequently was not neutral. ${ }^{25}$

The focus on scientific neutrality permeated lawyers' public commitments as well as their ideology. When they involved themselves with public affairs, attorneys usually concentrated on efforts such as civil service reform, lobby reform, secret ballots, corrupt-practices acts, the streamlining of court procedures, the removal of crooked judges, and the devising of procedures to select capable ones. ${ }^{26} \mathrm{Law}$ would govern best when politics was eliminated, which could occur only when neutral governing structures were devised.

\section{Building Cooperation From Conflict}

The theorists and practitioners of the scientific legal culture believed that the law's proper scope extended beyond judicial application of neutral rules. Although they rejected any state direction of the economy or, even worse, any redistribution of wealth, they did believe that law and the legal profession should facilitate cooperation to remove apparent social conflict. While they never fully articulated this concept, we can understand their outlook by examining it through the prism of an old idea-reciprocity-that modern theorists have refined and formalized. ${ }^{27}$

by many as agents of royal absolutism. The question of "law versus equity" implicated some of the most fundamental political cleavages in English society. See THEODORE F.T. PLUCKNETT, A CONCISE HISTORY OF THE COMMON LAW 193-95 (5th ed. 1956). Yet in the classical orthodox account, equity was simply a rational response to a technical legal problem.

22. William Nelson defines "formalism" as "the notion that social controversies $c$ [an] be resolved by deductions drawn from first principles on which all men agree[ ] or by inductions drawn from the 'evidence' of past decisions." William E. Nelson, The Impact of the Antislavery Movement Upon Styles of Judicial Reasoning in Nineteenth Century America, 87 HARV. L. REV. 513, 566 (1974).

23. See MORTON J. HORWITZ, THE TRANSFORMATION OF AMERICAN LAW, 1780-1860, at 253-66 (1977); see also, e.g., Humphrey's Executor v. United States, 295 U.S. 602, 624 (1935) (arguing that Federal Trade Commission "must, from the very nature of its duties, act with entire impartiality. It is charged with the enforcement of no policy except the policy of the law.")

24. See, e.g., Ives v. South Buffalo R.R. Co., 94 N.E. 431, 437 (N.Y. 1911) ("[U]nder our form of government ... . courts must regard all economic, philosophical, and moral theories, attractive and desirable though they may be, as subordinate to the primary question whether they can be molded into statutes without infringing upon the letter or spirit of our written Constitutions.").

25. See Benedict, supra note 8 , at 327-31.

26. See Grey, supra note 9, at 35 .

27. Social scientists have developed an impressive body of empirical research and abstract theory suggesting that social actors create binding rules without resort to a coercive centralized state, and moreover, can create situations where cooperation can evolve out of apparent conflict. While the best known of this research is the multiple play "Prisoner's Dilemma" game, analyses of other games suggest that cooperation and stability can arise in a decentralized social system. For an excellent description of this research, see ROBERT O. KEOHANE, Reciprocity in International Relations, in INTERNATIONAL INSTITUTIONS 
The basic idea of reciprocity is simple and intuitively powerful. Even if two parties conclude a mutually beneficial agreement, each party might still face the temptation to "defect," or cheat, either to get extra benefits or out of fear that the other party will cheat. One way of preventing such defections is to form a state with sufficient coercive power to force a promisor to honor its promise or compensate the promisee. In the absence of the state, however, reciprocity itself can often perform the same function. If the parties must deal with each other multiple times, then they will not defect for fear that future partners will refuse to deal with them due to their bad track record. The possibility of defection will drive both parties to set up rules establishing cooperation enforced by the threat of further defection. ${ }^{28}$

To make reciprocity work, the parties must clearly know their obligations and be able to tell easily whether an agreement has been violated. Consequently, agreements under a reciprocity regime must be transparent, that is, they must communicate information effectively. And clear legal rules dramatically increase transparency. ${ }^{29}$ Clear rules also enhance cooperation because they increase the parties' certainty as to an agreement's meaning. With clear interpretive rules and neutral institutions such as courts to interpret the law, parties will be more likely to agree because they do not have to expend resources in constructing interpretive rules themselves. ${ }^{30}$ Thus, law facilitates cooperation even without coercive enforcement. ${ }^{31}$

Reciprocity animated the scientific legal culture's adherence to "custom" as the origin of legal institutions. A good example is found in the writings of New York lawyer James Coolidge Carter, who argued that custom, which he saw as the basis of all law, was enforced by reciprocity. ${ }^{32}$ While at the beginning, some of this reciprocity was carried out by brute force, much of it involved nonviolent sanctions. ${ }^{33}$ More importantly, as people began to acquire

AND STATE POWER 132, 137 (1989) [hereinafter KEOHANE, Reciprocity].

28. Cf. id. at 137-38.

29. See Robert Axelrod, An Evolutionary Approach to Norms, 80 AM. POL. SCI. REv. 1095, 1106-07 (1986) ("The law tends to define obligations much more clearly than does an informal norm. A social norm might say that a landlord should provide safe housing for tenants, but a housing code is more likely to define safety in terms of fire escapes."); see also JOSEPH M. GRIECO, COOPERATION AMONG NATIONS 23 (1990) (noting "consensus that international cooperation cannot be separated from rule-governed state behavior and that rules may in fact be the most important element of international regimes or institutions").

30. See ROBERT KEOHANE, The Demand for International Regimes, in INTERNATIONAL INSTITUTIONS AND STATE POWER 110 (1989) (arguing that "a framework of rules, norms, principles, and procedures for negotiation . . . facilitate[s] the making of substantive agreements"); Carol M. Rose, Crystals and Mud in Property Law, 40 STAN. L. REV. 577, 608 (1988) (observing that clear rules "enhance sociability and facilitate ongoing social interactions").

31. It is true, of course, that a society governed by reciprocity is not necessarily cooperative, for reciprocity can entail unceasing violent conflict. See KEOHANE, Reciprocity, supra note 27, at 138-39. This is why the underlying harmony of interests-or at least conditions such as obtain in Prisoner's Dilemma, where there are more common than conflicting interests-is so crucial to making reciprocity desirable. The scientific legal culture could rely upon reciprocity, then, due to its perception of social interest.

32. See CARTER, supra note 11 , at 18 .

33. Carter emphasized community opinion as the most important sanction. Quoting Spencer, he noted that "before any definite agency for social control is developed, there exists a control arising partly from 
property, they sought to avoid violence in order to remove danger to that property; as a result, mechanisms of compulsory arbitration arose. ${ }^{34}$ Thus, legal systems existed before the appearance of any coercive state.

Reciprocity also drove the scientific legal culture's emphasis upon the clarity of legal rules: only if rules were clear could the legal system enhance reciprocity and thus facilitate cooperation. Grey observes that under Langdell's system, "the specific rules were framed in such terms that decisions followed from them uncontroversially when they were applied to readily ascertainable facts. Thus, classical orthodoxy sought objective tests, and avoided vague standards, or rules that required determinations of state of mind."35

Lawyers saw their role as facilitating cooperation even if it meant disagreeing with their not-so-enlightened clientele. No one exemplified this attitude more than Root himself, a leader of the New York bar. Root's most notorious client, the promoter Thomas Fortune Ryan, said of him:

Root was always keeping me out of trouble and prevented me from doing many things that I wanted to do .... In those days we generally issued bonds for the property but in the case of common stock and even preferred stock it was not considered necessary to have anything but water behind it-good will. Root always wanted to have value put in and to have the stock represent property. ${ }^{36}$

The law did not require the stock offering to be backed by property, but Root saw that the lack of backing would, in the event of a business failure, destroy the good will necessary for Ryan to operate. ${ }^{37}$

Most elite lawyers agreed with Root that the lawyer's job was to foster cooperation. For example, attorneys on corporate boards fought for conciliatory attitudes toward unions on the grounds that hostile antilabor policies actually hurt management. The argument rested upon reciprocity: if management cut wages, labor would resort to efficiency-impairing strikes or more subtle forms of resistance, and both sides would suffer. The idea, noted a business spokesman, rested upon the "sincere belief that the interests of the employer

the public opinion of the living, and more largely from the public opinion of the dead." Id. at 21 .

34. See id. at $41-42$.

35. Grey, supra note 9, at 11 (citation omitted). Game theorists argue that clear rules are necessary to prevent "cheating." The scientific legal culture perceived the same problem, but spoke of it in terms of corruption and bribery: powerful interests were attempting to break the rules of the political game. This situation was, of course, acutely embarrassing to those lawyers who represented corrupt interests. Professor Gordon notes, though, that lawyers saw legal science as the "reform instrument of first importance" because it would enable others to see corruption and retaliate by noncooperation. "[I]f legal rights could be made certain and procedurally effective, the advantages accruing from illegitimate tactics would simply disappear, and lawyers could keep their clients within the law." See Gordon, supra note 14, at 57.

36. 1 PhiliP C. Jessup, Elihu RoOT 186 (photo. reprint 1964) (1938); see also Henry L. Stimson Diary (May 21, 1924) (Sterling Memorial Library, Yale University) [hereinafter Stimson Diary] (recounting same story).

37. See BEALE, supra note 12 , at $46-47$, for a similar vision of the lawyer as conflict avoider. 
and employee are mutual and at bottom identical." Such a belief arose due to the influence of the bar. General Electric's Owen Young, himself a lawyer, argued that "the new idea in management ... sprang largely from the fact that lawyers were advanced to high managerial posts." ${ }^{38}$

Reciprocity played a vital ideological role in the scientific legal culture because it enabled lawyers, scholars, and judges to explain social conflict while simultaneously maintaining their belief in social consensus. What game theorists would now refer to as "defection," the legal culture saw as social conflict. According to this view, social conflict arose not from fundamental clashes of interest but from imperfect institutional arrangements: if those arrangements were improved, social conflict would disappear.

One theme, then, unified the various facets of the legal culture: social life could be legally regulated with minimal exertion of power. Construction of an ordered society did not require coercion. Despite appearances, all individuals in society essentially had harmonious interests. Thus, they could form binding agreements even in the absence of state coercion, because reciprocity would protect against cheating, and neutral legal principles would ensure that all disputes were arbitrated fairly. ${ }^{39}$ As Beale put it, "[t]here are only two possible methods of reconciliation: force, and law. Either the will of the physically strongest, or of the mentally alertest, must prevail-the way of the beast; or conflicting wills must be restrained by law-the way of organized human society. ${ }^{\prime \prime 4}$ That the way of organized society might rely upon the methods of the beast was not a proposition that Beale cared to entertain.

\section{IMPLICATIONS FOR INTERNATIONAL RELATIONS- "A SYSTEM OF LAW"}

The scientific legal culture carried implications for the conduct of American foreign policy. Primary among these was the idea that the international system could be regulated by legal means. Policymakers believed that the legal lessons America had learned internally applied to the external

38. Both statements quoted in DAVID BRODY, The Rise and Decline of Welfare Capitalism, in WORKERS IN INDUSTRIAL AMERICA 48, 50-51 (1st ed. 1980). Young's influence on U.S. foreign policy during the 1920's was profound. COSTIGLIOLA, supra note 1, at 24, equates his importance with Hughes, Herbert Hoover, and Henry L. Stimson. Reciprocity also affected regulatory policy. For example, the "sunshine" approach, embodied in the Bureau of Corporations, saw the regulator not as a coercive agent but as a collector and disseminator of information that enhanced reciprocity-and thus cooperation-by helping firms detect cheating. Furthermore, a "sunshine" regulatory agency would "cleanse corporate practice through the medium of public scrutiny," again allowing reciprocity-in this case, public outrage-to control behavior. See Robert L. Rabin, Federal Regulation in Historical Perspective, 38 STAN. L. REV. 1189,1219 (1986).

39. This is why reciprocity was not "coercive" for the scientific legal culture. It was not "coercive" for one actor to withhold cooperation from another if the second actor wanted a more equal bargaining position, but nevertheless stood to gain from cooperation. True to the scientific legal culture's assumptions, considerations of power never entered the equation. See Coppage v. Kansas, 236 U.S. 1 (1914) (holding legisiation banning "yellow dog" labor contracts was unconstitutional impairment of freedom of contract).

40. BEALE, supra note 12 , at $44-45$. 
realm as well. President Coolidge summed it up in typically succinct form when he stressed that Republican public policy "represent[s] the process of reducing our domestic and foreign relations to a system of law. They consist of a determination of clear and definite rules of action. It is a civilizing and humanizing method adopted by means of conference, discussion, deliberation, and determination." 41 No one denied the value of the police. But the belief that law sprang from consensual custom and the conviction that reciprocity formed the basis of enforcement powerfully suggested a basis for international legal order. It implied that individuals could make effective agreements in the absence of state coercion, and thus also implied that nations could do the same.

Policymakers asked three questions. First, did nations have the common interests necessary to make mutually beneficial agreements regulating their international acts? Second, could these agreements be written and interpreted in such a way as to be neutral and fair to all sides? Third, could they be enforced without resort to some international police force? The scientific legal culture suggested that the answer to all three questions was yes.

We can see in retrospect this formulation's weakness. It was grounded in the conviction that states try to maximize their gains from any agreement. Such a belief appears very hard-headed, but this appearance obscures the view's focus on absolute gains to each party rather than relative ones. The traditional questions of international relations concern the relative distribution of benefits within the international system. Thus, the scientific legal culture's assumptions were actually optimistic.

But such relatively optimistic assumptions played a crucial role. Acknowledging that some groups might be concerned with relative gains, or that there did not exist enough mutual interests to conclude voluntary agreements, would effectively dash any hopes for real domestic consensus. It would amount to conceding that the scientific legal culture's entire project was destined for failure. Denying the relevance of relative gains thus served the culture's most crucial ideological needs. The scientific legal culture recognized, of course, that the underlying mutuality of interests did not lead automatically to a world without conflict. The ideas concerning reciprocity and cooperation thus provided legal thinkers with the ideal method for reconciling the brute fact of social conflict with the firm belief in mutual interests. Conflict existed because legal institutions that would allow parties to cooperate did not exist. ${ }^{42}$

41. Calvin COOLIDGE, Speech of November 19, 1925, in Foundations of THE REPUblic: SPEeCHES AND ADDRESSES 328-31 (1926). Coolidge's reference to "clear and definite rules of action" reflects the classical orthodox emphasis on formal realizability and his noting of the "conference" method recalls the idea of legal institutions facilitating cooperation.

42. Such a view of conflict-and conflict avoidance-bears remarkable resemblance to the modern-day international relations school known as "neoliberal institutionalism." Neoliberal institutionalists emphasize the importance of international "regimes" in preventing conflict and enhancing cooperation. These regimes perform the critical functions of iterating Prisoner's Dilemmas and lowering transaction costs to make more international agreements possible. Regime theorists do not limit their view to legal institutions, but their 
Thus, the foreign policy influenced by the scientific legal culture saw its central tasks as the construction of worldwide treaty system ${ }^{43}$ and the legal and quasi-legal institutions to enforce those treaties. First, the United States would seek to conclude treaties with other nations to put their relations upon a proper legal footing. This would allow the reciprocity mechanism to work, because upon the discovery that a nation had broken its treaty obligations, other nations could break theirs, thus depriving the original offender of its gains from signing the original agreement. Second, institutions would adopt rules of decision that were neutral and nonpolitical: only if the rules of the game were divorced from political considerations would all the relevant social actors accept them and be assured that they would gain from cooperation. Third, they would maximize transparency in order to ensure effective reciprocity: rules would reflect general principles but also would be specific enough to measure the particular rights and duties of the parties involved. This specificity would then yield cooperation in addition to enforcement: the knowledge that nonpolitical institutions promulgated neutral rules enforced by reciprocity would encourage parties to make firm commitments.

Such was the vision that the scientific legal community fostered, and the one that animated Root and Hughes in their construction of foreign policy during the 1920 's. It is to those contours that we now turn.

\section{ELIHU ROOT}

Root rarely held official positions during the decade. Yet his overall influence extended broadly over G.O.P. foreign policy, both historically and institutionally. ${ }^{44}$ If anyone created the eastern foreign policy establishment, it was Elihu Root. With the exception of Henry Cabot Lodge, Root carried more experience in foreign affairs than all other party luminaries combined. Thus, he set the paradigm in which GOP internationalism would function: if the party were to avoid isolationism, it would be on Root's terms. ${ }^{45}$

analysis of the function of international institutions is essentially the same as the scientific legal culture's analysis of domestic legal institutions. It should be emphasized that neoliberal institutionalism is a more complex and sophisticated theory than that of the scientific legal culture. Neoliberal institutionalists argue that they explicitly take into account international power and often agree with Realist predictions; their theory claims to subsume Realism, not replace it. See ROBERT O. KEOHANE, Neoliberal Institutionalism: a Perspective on World Politics, in INTERNATIONAL INSTTTUTIONS AND STATE POWER 3 (1989).

43. In this vein, the introduction to a volume of Hughes' addresses as Secretary of State boasted prominently that in only four years, he had negotiated 69 treaties and conventions with other nations, in addition to many other international agreements that could be concluded solely by the Executive. See Publishers' Note in Charles Evans Hughes, The Pathway of PEACE, at ix (1925).

44. Root served as Secretary of War from 1899 to 1904 and as Secretary of State from 1905 to 1909. His efforts on behalf of international arbitration won him the Nobel Peace Prize in 1912. He founded and served as president of the American Society of International Law and the Council on Foreign Relations. For a well-written account of Root's career, see generally LEOPOLD, supra note 4.

45. For discussions of Root's overall influence in Republican foreign policy, see generally 2 JESSUP, supra note 36; LEOPOLD, supra note 4. 
Root's terms were unmistakably legal. He consistently maintained that the only stable international system was a legally regulated one. The First World War only strengthened his faith in international law. The assumptions that he received from his legal background remained solid.

\section{A. The Basis of Authority}

Like most late nineteenth-century legal thinkers, Root perceived the state as a negligible force in maintaining social order. "It is only for the occasional nonconformist that the sheriff and policeman are kept in reserve," he asserted, "and it is only because the nonconformists are occasional and comparatively few in number that the sheriff and the policeman can have any effect at all." Instead, "[1]aws are capable of enforcement only so far as they are in agreement with the community in which they are to be enforced ... For the great mass of mankind, laws established by civil society are enforced directly by the power of public opinion." 47

In keeping with the assumptions of the scientific legal culture, Root contended that international legal structures "shall be developed naturally from the customs, the habits of thought and action, and the standards of conduct in which civilized nations agree." driven by consensus. "[W]e should remember," he argued,

that the real power behind international as well as national progress towards better conditions is public opinion .... That is the power behind all human law and all custom. If a statute rightly reflects the opinion of the people for whom it is passed, or is adapted to give effect to that opinion, it gets itself enforced. If the contrary is true, the law fails of effect. ${ }^{49}$

\section{B. The Evolution of Cooperation}

Order, however, did not emerge spontaneously, but required the conscious, rational behavior of social actors for the law to "get[] itself enforced." Conflicts would arise, but actors would see that their own interests would suffer if they did not cooperate. Thus, legal enforcement was a consensual

46. ELIHU ROOT, THE SANCTION OF INTERNATIONAL LAW 7, in INTERNATIONAL CONCILIATION 1908 (Doc. No. 8, July 1908) [hereinafter ROOT, SANCTION]. For Root, tyranny was possible but fundamentally unstable: no state could maintain order simply by force. Social peace "can never be except as it is founded upon justice." Elihu ROOT, CAUSES OF WAR 4, in INTERNATIONAL CONCILIATION 1909 (Doc. No. 18, March 1909) [hereinafter ROOT, CAUSES].

47. ROOT, SANCTION, supra note 46, at 6-7.

48. EliHu ROOT, PRESIDENTIAL ADDRESS AT THE FIfTEENTH ANNUAL MEETING OF THE AMERICAN SOCIETY OF INTERNATIONAL LAW 14, in INTERNATIONAL CONCILIATION 1921 (Doc. No. 165, Aug. 1921) [hereinafter ROOT, PRESIDENTIAL ADDRESS].

49. Elihu Root, Steps Toward Preserving Peace, 3 FoREIGN AFF. 351, 352-53 (1925) (emphasis added) [hereinafter Root, Steps]. 
process rooted in reciprocity. "Conformity to the standard of business integrity which obtains in the community is necessary to business success," argued Root. "It is this consideration, far more frequently than the thought of the sheriff with a writ of execution, that leads men to pay their debts and to keep their contracts."

Law played a necessary role in initially forming this community. What "makes a common public opinion possible," Root said, is "the building up of standards of conduct ... accomplished by the formulation and establishment of rules that are gradually being taken out of the domain of discussion into that of general acceptance."51 International legal institutions were critical because they provided the vehicle for the power of public opinion. ${ }^{52}$ The question remained, though, as to how this mechanism would operate. For Root, the answer was clear: institutions would identify nations that were untrustworthy. Thus, nations would have strong incentives to abide by legal injunctions, or face the possibility that no other nation would cooperate. "We have a treaty with Great Britain," he noted,

under which we have agreed that all questions arising upon the interpretation of treaties shall be submitted to arbitration; and, while it seems hardly conceivable, yet there are men who say that we will never arbitrate the question of the construction of that treaty; but I say to you that if we refuse to arbitrate it, we will be in the position of the merchant who is known to all the world to be false to his promises. $^{53}$

In other words, reciprocity would ensure that nations would keep their agreements. Root did not have the formal analytic tools of modern game theory, but the reasoning was the same:

[I]f an international court were established and commended itself to the people of the world by its conduct, there would after a time grow up a universal public opinion which would discredit any nation that refused to submit a question of right to the court and undertook

50. ROOT, SANCTION, supra note 46 , at 7 .

51. Id. at 9 .

52. "[T]he question inevitably arises," Root observed,

'How is it that nations composed of people who don't want war are continually fighting?' The answer is that the opinion against war has been without adequate institutions to give it effect. War is an international affair; and to prevent it there must be international opinion, and international action upon that opinion, and international institutions to give effect to that opinion.

Root, Steps, supra note 49, at 353; see also ELIHU RoOT, THE OUTLOOK FOR INTERNATIONAL LAW 20, in INTERNATIONAL CONCILIATION 1916 (Doc. No. 100, Feb. 1916) [hereinafter ROOT, OUTLOOK]; Stimson Diary, Sept. 24, 1930 (noting that Root saw World Court as critical priority for U.S. foreign policy); Id., Dec. 12, 1930 (observing that Root saw World Court as "engine of peace").

53. EliHu RoOT, THE SPIRIT OF SElf-GOVERNMENT 12-13, in INTERNATIONAL CONCILIATION 1913 (Document No. 62, Jan. 1913) [hereinafter RoOT, SPIRIT]. 
instead to enforce its own opinion by war. People generally would not have to argue out the rights and wrongs of the controversy. Public opinion would properly turn in favor of the nation that was willing to submit its claims of right to adjudication and against the nation which was unwilling to do so. ${ }^{54}$

International institutions fostered cooperation not only through reciprocity but by reducing the costs of making agreements in the first place. In keeping with the scientific legal culture's conviction that perceived fundamental interest conflicts were in fact illusory, Root argued that the costs of agreements were needlessly raised by factors such as mistrust and cynicism, which prevented parties from seeing their true common interest. ${ }^{55}$ He reasoned that such costs could be reduced-and had been reduced historically-through the device of the diplomatic conference. The conference had been effective because it enabled nations to dispel both diplomatic irritations and falsely perceived clashes of interests. "Whether it be by dispelling misunderstandings, allaying fears ... or by the repressive effect of general adverse opinion, a formal general conference of the principal nations," he contended, "leads to a situation in which it is extremely difficult for any nation to begin war." B6 But the mechanism for calling conferences had previously been inadequate to the task:

The weakness of the practice hitherto has been ... that no one had a right to insist upon a conference; no one was under obligation to attend a conference. The step ... plainly indicated as the natural development of this most useful practice into a systematic institution, is to establish an administrative agency whose duty it shall be to call such a conference in time of threatened danger . . . and to place all nations under obligation to attend the conference when called. ${ }^{57}$

Thus, Root argued that international institutions, if properly designed, could facilitate agreements by reducing the costs of reaching them. Root saw this not as a marginal improvement in the international system, but as a fundamental change: "[I]f Sir Edward Grey had secured the conference he sought in July, 1914," Root asserted, "the war would have been averted."

54. Root, Steps, supra note 49 , at 354-55.

55 .

War comes to-day as the result of one of three causes: either actual or threatened wrong by one country to another, or suspicion by one country that another intends to do it wrong, and upon that suspicion, instinct leads the country that suspects the attack, to attack first; or, from bitterness of feeling, dependent in no degree whatever upon substantial questions of difference; and that bitterness of feeling leads to suspicion, and suspicion in the minds of those who suspect and who entertain the bitter feeling, is justification for war. It is their justification to themselves. The least of these three causes of war is actual injustice.

ROOT, CAUSES, supra note 46 , at 5-6.

56. ROOT, PRESIDENTIAL ADDRESS, supra note 48, at 16.

57. Id.

58. Id.; see also Charles W. Toth, Elihu Root, in AN UNCERTAIN TRADImION: AMERICAN SECRETARIES 
There it was. The war did not result from irreconcilable interest conflict, but rather from international institutional weakness. Had proper international institutions existed, then "public opinion"-which was presumed to be unified-would have rallied to those powers seeking to avoid conflict. Warmongering leaders would have been unable to begin hostilities because their respective populaces would not have let them. Thus, the Great War was not merely catastrophic, but tragic because it was so easily preventable. ${ }^{59}$

Root recognized that conferences differed in important respects from international tribunals. Most importantly, the former focused upon "matters of policy," while the latter resulted in "judicial disposal of questions of right." Conferences were "not steps in the development of the rule of right among nations." ${ }^{.61}$ Still, nations were legally obliged to heed the agency's call for a mandatory conference. In this sense, Root's vision of conferences mirrored his idea for arbitration because both were set in action by a principle of legal obligation and enforced by public opinion. ${ }^{62}$ As Root himself noted, they "are not alternative and opposing methods. They are mutually supplemental parts of one and the same scheme to prevent war. Both are methods of bringing the public opinion of the world to bear upon the settlement of controversies. Neither covers the field without the other." 63

International institutions, then, served as powerful bulwarks against international conflict; their absence caused Europe's self-destruction in 1914. Law's noncoercive nature could prove effective in international dispute resolution as it had domestically, by inducing cooperation through reciprocity and reducing the transaction costs that made international agreements more difficult. For Root, the problem of international instability could be solved without resort to force.

\section{A Case Study: Root and the Versailles Treaty}

Root played a leading role in the Republican Party's opposition to Woodrow Wilson's peace program in 1919. Root's alternative principles galvanized G.O.P. opposition throughout the treaty fight, providing a coherent

of State in the Twentieth Century 40, 55 (Norman A. Graebner ed., 1961).

59. Hughes saw the war's origins similarly. He praised the portion of the League of Nations covenant that provided for mandatory calling of conferences because "it gives voice to the lesson of the great War. It provides machinery for consultation, mediation, and conciliation." Charles Evans Hughes, "The Proposed Covenant for a League of Nations," Address Before the Union League Club of New York City (Mar. 26, 1919) (Box 172, Charles Evans Hughes Papers, Library of Congress) [hereinafter Hughes Papers].

60. ROOT, PRESIDENTIAL ADDRESS, supra note 48, at 20.

61. Id. at 16.

62. See ROOT, SANCTION, supra note 46 , at 12: "[H]owever complicated the question in dispute may be, the proposition that it should be submitted to an impartial tribunal is exceedingly simple." Similarly, no matter how vexed a diplomatic question might be, the idea that it should be solved at a diplomatic conference was exceedingly simple. Both institutions could mobilize the opinion of the international community to give them legal force.

63. ROOT, PRESIDENTIAL ADDRESS, supra note 48, at 20. 
internationalist alternative to Wilson's concept of the League of Nations and drawing strength from the scientific legal culture's assumptions.

At the beginning of the treaty fight, the Republicans' razor-thin majority in the Senate ${ }^{64}$ could agree on little else except its opposition to Wilson's program. All Republicans felt that Article Ten of the League Covenant ${ }^{65}$ threatened to impose on the United States an all-encompassing obligation to police the world, but beyond that, they could agree on little else. Senate Foreign Relations Committee Chairman Henry Cabot Lodge and Republican Party Chairman Will Hays asked Root to formulate a positive G.O.P. program. By the end of March 1919, he had done so, in keeping with the principles of the scientific legal culture. ${ }^{66}$ Four facets of Root's argument stand out. ${ }^{67}$

First, just as the scientific legal culture strictly separated law and politics, Root neatly divided the causes of war into legal and political categories. Arguing that "the world is ready for obligatory arbitration of justiciable questions," ${ }^{, 68}$ Root condemned the Treaty's lack of provisions for such compulsory arbitration. Second, he noted prominently that the Treaty failed because it made no provision for the codification of international law, which would have increased transparency and facilitated reciprocity. Third, to handle the political causes of wars, Root praised Articles 11, 12, 15, and 16 of the draft Covenant because they established provisions, through the League Council, for mandatory calling of international conferences to settle disputes. This reflected Root's-and the scientific legal culture's-view of quasi-legal conciliation institutions as facilitators of cooperation. Such a view contrasted sharply with Wilson's, who argued that without Article Ten, "the Covenant would mean nothing." Ten. ${ }^{70}$ The Article, Root felt, would force upon the United States potentially limitless obligations, but he supported the League with this reservation.

Wilson's response was uncompromising: either the Treaty would be approved as negotiated, or nothing would be approved. Wilson refused to compromise even after the Senate rejected the Treaty twice. Such presidential intransigence unified the Republican Party throughout 1919, and Root's reservations attracted the support of the majority of Republican senators. ${ }^{71}$

64. The 66th Senate contained 49 Republicans and 47 Democrats.

65. Article Ten committed each League member to "preserve as against external aggression the territorial integrity and existing political independence of all members of the League." See N. GORDON LEVIN, JR., WOODROW WILSON AND WORLD POLITICS 179 (1968).

66. See Lloyd E. AMBrosius, WOODROW WILSON AND THE AMERICAN Diplomatic TRAdiTION 103 (1987) ("Following the tradition of Republican administrations in the late nineteenth and early twentieth centuries, Root emphasized legal procedures to preserve peace.").

67. Letter from Root to Henry Cabot Lodge (June 19, 1919) (Box 161, Elihu Root Papers, Library of Congress) [hereinafter Root Papers].

68. Id.

69. Quoted in AMBrosius, supra note 66, at 142.

70. Letter from Root to Henry Cabot Lodge (June 19, 1919) (Box 161, Root Papers).

71. See AMBRosius, supra note 66, at 244-45 (noting that by 1920, France supported Treaty ratification with reservations, which "coincided with the Republican majority's position rather than 
Legalist assumptions permeated Root's program. Codification of international law and compulsory arbitration served as critical pillars of a cooperative order. Arbitration facilitated reciprocity because the nation that refused arbitration would clearly be marked as the wrongdoer. In the same way, codification would give nations a clearer yardstick by which to measure other nations' behavior. In keeping with the assumptions of the scientific legal culture, Root never doubted that these institutions could transcend politics, and he felt that no international settlement would be stable without them.

Of equal interest is Root's attachment to the League without the obligations of Article Ten. Wilson regarded Article Ten as the key to the Covenant because it mandated the coercive power of any collective security system. On this line of thinking, without Article Ten, the whole League apparatus meant nothing. For Root, however, the League represented the sort of conciliation mechanism that would have forestalled war in Europe in $1914 .{ }^{72}$ The mere fact of the mechanism would have identified the aggressor by its nonparticipation, and other nations would shun this aggressor out of their own self-interest even if they were not legally obliged to do so. ${ }^{73}$ The institution's mechanism outweighed its members' specific commitments.

But that did not mean that Root and the Republicans failed to take international law seriously. The best evidence for the thesis that the G.O.P. placed enormous importance upon international law lies in their antipathy to Article Ten. Had they truly been skeptical of international law's efficacy, they would not have endangered the entire treaty process by opposing it. Instead of seeing Article Ten as a mere paper guarantee, they believed that it had potential to entangle the U.S. in endless commitments that it would be legally bound to honor or suffer the consequences of international pariah status. Republican seriousness about international law only heightened after Wilson

Wilson's"). Ambrosius counts anywhere from 7 to 14 "Irreconcilables" opposed to the Treaty in any form, leaving 35 to 42 pro-Treaty Republican reservationists. Id. at 230 . The final blame for the Treaty's failure, then, lies not with the Republicans but with Wilson, whose opposition to all plans but his own prevented a bipartisan compromise. The ironic result was that even though a vast majority of senators from both parties favored U.S. participation in the League, such participation was never a realistic political alternative. Id. at 289 (noting "tacit alliance between Wilson and the irreconcilables. . . . Unable to control American foreign relations, [Wilson] preferred to isolate the United States from Old World.").

72. Hughes shared this view. See Memorandum of Interview with the French Ambassador held in the Office of the Secretary of State (Mar. 30, 1921) (Box 157, Hughes Papers) ("Secretary Hughes [said] that the [Versailles] Peace Conference had departed from the original idea of the League of Nations by making it not only an instrument for conference and conciliation, with a view toward preserving the peace of the world, but also by charging it with certain definite duties in connection with the enforcement of the terms of the Treaty, and that the opposition of the American people to the League had grown after seeing it in operation .....")

73. Root realized that the provision in the Covenant calling for unanimity in the League's Executive Council in order to activate Article Ten made it virtually impossible that it would ever actually operate. But "he did believe that the very existence of the Council with its regular procedure for conference would be very important and from it would grow the kind of safeguard of peace which all wanted to secure." 2 JESSUP, supra note 36 , at 395. 
argued that Article Ten was a moral obligation, but not a legal one. ${ }^{74}$ This infuriated Root because it suggested, in contrast to legal orthodoxy, that legal obligations did not reflect the moral sense of the community. ${ }^{75}$ In other words, Wilson's distinction denied what Ames, Beale, and other legal thinkers had already demonstrated was true: law reflected a natural order based upon consensual community norms. The treaty fight, then, shows that the Republicans took international law more seriously than did Wilson, supposedly the apostle of international legalism. When Warren Harding triumphed in the election of 1920, these mildly pro-League Republicans emerged at the helm of the new administration's foreign policy. One of their leading exponents, Charles Evans Hughes, played the leading role as the Secretary of State.

\section{Charles Evans Hughes}

Hughes, Secretary of State from 1921 to 1925 , was the principal exponent of American foreign policy throughout the decade. The weak-willed Harding and his successor, Calvin Coolidge, rarely concerned themselves with foreign affairs, leaving the field to their subordinates. And of those subordinates, only Secretary of Commerce Herbert Hoover approached Hughes' authority to speak for the administration on foreign policy. Hughes' influence extended far beyond his tenure as Secretary of State. The biographer of his successor, Frank Kellogg, speaks of Kellogg's "almost abject dependence" on Hughes' judgment when critical matters arose. ${ }^{76} \mathrm{How}$, then, did Secretary Hughes perceive the international system? His thought is more complex than Root's, and at times he even appears to be an old-fashioned realist. But his overriding faith in the separation of law and politics, combined with his conviction that neutral principles would manifest themselves effectively in concrete institutions, maintained his faith in international law as the bulwark of peace. ${ }^{77}$

74. See AMBrosius, supra note 66 , at 165.

75. See Letter from Root to Henry Cabot Lodge (Aug. 28, 1919) (Box 161, Root Papers).

76. L. EThan Ellis, Frank B. Kellogg aNd AMERICAN FOREIGN RELATIONS, 1925-1929, at 233 (1961). Ellis also notes that Kellogg had a similar sort of dependence upon Root. Id.

77. No discussion of Hughes can ignore the acute political pressure that he faced from Senate Irreconcilables, and one could argue that Hughes' public statements, upon which this Note often relies, are better seen merely as political fodder. Such a view, however, ignores the remarkable resemblance between Hughes' public statements and his private communications. See BETTY GLAD, CHARLES Evans Hughes AND THE ILLUSIONS OF INNOCENCE 3 (1966). If anything, the opposite is true: given isolationist sentiment in the Senate, any statements concerning the necessity of international institutions figured only to harm Hughes politically. Hughes retreated from even mild support for the League of Nations after taking office for political purposes. See Letter from Hughes to A. Lawrence Lowell (July 14, 1922) (Box 447, Warren G. Harding Papers, Ohio Historical Society) (microfilm). It stands to reason that when the Secretary proposed expanding the reach of international institutions, he meant it. 


\section{A. The Central Problem}

At first glance, Hughes appears to suffer from multiple personality disorder. Aware of international conflict, Hughes seemed to make an excellent case that international institutions could never reform that system. He would often begin his addresses with pessimistic warnings concerning the human tendency towards violence and the fragility of international institutions. ${ }^{78}$ Yet he refused to carry these views to their logical conclusion, and insisted that balance-of-power politics was doomed to fail. ${ }^{79}$

The foregoing suggests that Hughes was some sort of fatalist. If human passions caused disputes, radical changes in international law could not prevent those disputes from becoming violent, and the threat of force could not prevent international conflict, either. But in fact, Hughes was very optimistic about the international system. How was this possible? The answer lies in examining the legally based assumptions that animated Hughes' world view.

\section{B. Law Versus Politics}

At the heart of the scientific legal culture lay the sharp distinction between law and politics. This distinction, for Hughes, represented the best hope for the legal regulation of international affairs. Virtually every foreign policy address Hughes delivered began with the standard disclaimer outlined above, and virtually every one concluded with a ringing affirmation that a legally regulated international system was feasible and possible. This was because Hughes saw the diplomat's central task as the transformation of international controversies from political ones into legal ones: law could not force nations to agree, but once they did agree, putting their agreement into the legal form of a treaty would make it susceptible to impartial adjudication.

Hughes held the same background assumptions concerning the law/force dichotomy as did Root and the rest of the legal culture. The state was unimportant: what mattered, for law, was consent. "The notion of law as imposed and maintained by force," he argued, "may have its advantage in dealing with a small minority of infringers, but in the long run this notion derogates from its authority and counts for much of the natural revolt against legalistic conceptions." In the domestic sphere, he continued, obedience to law "finds its motive not in yielding to force, but in the recognition of the law as the expression of the democratic will through representative institutions."

78. See, e.g., Charles Evans Hughes, The Pathway of Peace, in The Pathway of Peace, supra note 43, at 5-8 [essay cited hereinafter as HuGHES, Pathway].

79. See, e.g., id. at 6; see also Charles Evans Hughes, Some Observations on Recent Events, 1926 PROC. AM. SOC'Y INT'L L. 2 [hereinafter Hughes, Observations]; Charles Evans Hughes, The Development of International Law, 1925 PRO. AM. SOC'Y INT'L L. 5 [hereinafter Hughes, Development] (cautioning against returning "to the old instinctive process of self-protection through the balance of power"). 
Similarly, then, international law would develop the same way. "Taking the long view, it may not be regarded as a defect or a misfortune that we escape the notion of the impositions of force in the field of international law."80

Why would states give their consent? Because the law, unlike politics, was unbiased. It represented a set of neutral principles that were fair to all parties. Just as important, it was administered by an impartial judiciary. Hughes considered the character of the adjudicators to be critical. This precisely followed the scientific legal culture. Professor Gordon has observed that if, for the very different legal scientists of the antebellum period, the critical characteristic of judges was "virtue," then for their late nineteenth-century successors, the byword was "integrity." ${ }^{\prime 1}$ The notion of integrity of bench and bar underlay the legal culture's faith in neutral legal development.

Hughes saw the international application of the integrity notion as a key to judicial efficacy. After his usual warning against over-optimism, he asked,

What is the remedy? The alternative to war, where agreement has been found impossible, is in some sort of arbitral settlement. But ... no arbitral arrangement can escape the imperfections which inhere in human nature. Obviously the best thing that can be done is to select the judges before the controversy arises; to choose them for their preeminence in learning, their approved characters, their impartiality; to set them aside with a secure tenure; to immunize them so far as possible by the dignity and continuity of their office from the prejudices and preoccupations of politicians; gradually to promote confidence in their decisions by the observation of their judicial practice; in short, to establish under the best practicable safeguards a permanent court. Such an institution has at last been set up and it holds the promise of the security of rights. ${ }^{82}$

Judges with the requisite character and integrity were critical if the law/politics distinction were to be maintained and international law were to command the same respect as domestic law. Hughes explicitly made the analogy to domestic judicial institutions, and argued that impartial neutrality would give the same authority to international institutions. ${ }^{83}$ The Supreme Court's authority and power, argued Hughes, derived not from its decision being enforced by the Executive, but from the universal consent its impartial judgments brought. ${ }^{84}$ Even the most impartial judges, of course, could not play this depoliticizing function had law been seen as inseparable from politics.

80. Hughes, Development, supra note 79 , at 3.

81. See Gordon, supra note 9 , at 98.

82. Hughes, Observations, supra note 79 , at 7.

83. Id. at 7-8; $c$. text accompanying note 41 .

84. Of interest, of course, is Hughes' belief that the Court was nearly universally loved-a scant ten years after the Republican Party had been split in two over the question of popular recall of judges, and only a decade before a major constitutional crisis would result from the Court's flouting of the popular will. See, e.g., GEORGE E. MOWRY, THE ERA OF THEOdORE ROOSEVELT, 1900-1912, at 264-65 (1958). 
But the law/politics separation was axiomatic. Upon this axiom rested Hughes' support for the World Court. "The problem in the improvement of the judicial process in international relations," he argued, "is to secure immunity, so far as is humanly possible, from considerations of political interest and policy and to have the rights and obligations of nations determined upon their merits." 85

Hughes never doubted that taking politics out of international affairs was possible. ${ }^{86} \mathrm{He}$ strongly supported the codification of international law as a means of making the law more precise and impartial and saw it as similar to the American Law Institute project of restating domestic law for the same ends. Hughes even referred to the codification project as a "restatement." 87

Hughes maintained an ability to believe that legal rules were neutral even when they involved the most hotly-disputed domestic political issues. Arguing that general and neutral principles of international law could succeed in world politics, he cited as a model the U.S. Constitution's commerce clause, which had met "with general approval" even though it had to be applied in numerous contested cases-just before that clause became a lightning rod for political debates surrounding the New Deal. ${ }^{88}$ His ability to see neutrality in highly controversial issues extended even to German reparations, an issue that formed the crux of international disputes during the decade. France, to whom most reparations were owed, knew that Europe would never recover unless Germany was freed of the crushing reparations burden. Yet on the other hand, if Germany was freed of the burden, it would quickly dominate Europe through its inherent economic and demographic strength, endangering France. The issue thus implicated basic issues of power politics. Yet Hughes nevertheless insisted that "the question should be taken out of politics." ${ }^{89}$ His mechanism resonated with the late nineteenth-century language of neutral integrity:

35. Charles Evans hughes, address By the Secretary of State of the United States BEFORE THE AMERICAN SOCIETY OF INTERNATIONAL LAW, April 27, 1923, at 85, 90-91, in INTERNATIONAL ConCiliation 1923 (Doc. No. 186, 1923) [hereinafter Hughes, PERManent CouRT].

86. For instance, in a contentious border dispute between Chile and Peru, Hughes established a procedure for what he felt would be fair elections. Henry Stimson, who worked with Hughes, worried that "[t]he [arbitration decision] assumes that a fair election can be held under conditions where I have very grave doubt that it can or ever could be held." Stimson suspected that in the decision, "Hughes' political philosophy stands out on every page," and he was right: Hughes assumed that formally fair procedures ensured stability by protecting against cheating and harmonizing interests. Stimson Diary, May 28-29, 1926.

87. See Hughes, Development, supra note 79, at 10. For the connection between Langdellian classical orthodoxy and the original project of Restatements, see GILMORE, supra note 19, at 58-64. Hughes enthusiastically adopted Francis Lieber's old idea for a restatement of international law "“whose whole authority should rest on the inherent truth and energy of their own proclamations." Hughes, Development, supra note 79, at 11 . International rules were a matter of "inherent truth and energy," not an alwayscontested controversy implicating vital national interests.

88. Charles Evans Hughes, Institutions of Peace, 1929 PROC. AM. SOC'Y INT'L L. 1, 5 [hereinafter Hughes, Institutions].

89. Charles Evans Hughes, Some Aspects of Our Foreign Policy, in The Pathway of PEACE, supra note 43, at 32, 56-7 [hereinafter Hughes, Aspects]. 
Why should [statesmen] not invite men of the highest authority in finance in their respective countries-men of such prestige, experience, and honor that their agreement upon ... a financial plan for working out the payments, would be accepted throughout the world as the most authoritative expression obtainable? ${ }^{90}$

The overall point was that politics could be sufficiently abolished in international affairs to establish basic order, in the same way that the law had minimized politics in domestic affairs. A lifelong politician, Hughes certainly knew that politics could never be abolished. Its field, however, could be sufficiently narrowed so that politics would never threaten the social order.

\section{B. Building Cooperation}

Hughes saw law not simply as a neutral basis for social order but also as a dynamic force that built social cooperation. Law performed this function in three ways. First, it created clear and transparent rules, facilitating reciprocity and making it more difficult for nations to break agreements. Second, it lowered the costs of making agreements. Third, it captured the "law-abiding sentiment" created by nonlegal institutions such as conciliation mechanisms, thus preserving gains won through nonlegal means.

Law enhanced reciprocity by increasing clarity in international relations. If worldwide public opinion knew that a nation broke its obligations, it would be much more difficult for that nation to improve its international position. "The truth is," asserted Hughes,

that the decisions of the court will have the most solemn sanction that it is practicable to obtain. When nations agree to submit a dispute to a tribunal and to abide by the decision, its observance is a point of international honor of the highest sort. You can really have no better sanction than this .... ${ }^{91}$

Similarly, the process of international legal codification would expose those "obstacles raised by purely selfish interests" and create "something definite ... upon which the organs of public opinion could concentrate."92

Hughes' faith derived from the premises of the scientific legal culture. Since law was a science, and legal rules were formally realizable, legal rules would be enforced. Hughes acknowledged that " $t]$ ]he contention that rules laid down in time of peace will not avail when war comes gains plausibility by reference to ... the instinct of self preservation, to the temptation to strike a

90. Id. at 57 .

91. Hughes, PERMANENT COURT, supra note 85 , at 342.

92. Hughes, Development, supra note 79, at 6. 
blow so terrible in effect that resistance would be impossible ...." But, he contended, "th[is] argument can be, and usually is, pressed too far":

The point is ... that the lack of definite agreements is in itself a grave temptation to inordinate excesses, and that clear and binding agreements should be obtained to the fullest extent practicable,- -agreements demanded by public opinion in civilized nations. It is too much to say that rules definitely expressed and agreed upon will be deliberately broken, especially such rules the breach of which would outrage the sentiment of the world. Government can now adopt such rules, if they are so disposed, with every reason to expect their observance if they do adopt them and make them sufficiently clear. ${ }^{93}$

Agreements would be followed because the consequences of noncompliance would simply be too great: the violator would be ostracized and reviled. Treaties, if specific enough, could enforce themselves.

But law also fostered cooperation because judicial resolution of disputes was easy and relatively cheap for nations. International legal institutions not only reduced the domestic political costs of treaties but also provided default principles:

When uncertainty of meaning appears at the time of some particular test, it is naturally asked why was the treaty not made more explicit? The answer may well be, in a Hibernian mode of expression, that if the treaty had been more explicit there would have been no treaty. The parties ... could go along together a certain way, but no farther; they preferred not to sacrifice the gain that they were making in their definite promises by an attempt to secure more and thought it better to leave the agreement to the process of interpretation in the light of the principles of law, rather than to wreck their hopes by insistence on particular clauses. ${ }^{94}$

Thus, international law reduced the costs of cooperation by settling controversies that actually were unforeseeable. Nations could submit difficult questions to impartial adjudication instead of having to renegotiate sensitive international agreements repeatedly. ${ }^{95}$ Each agreement, then, would last longer and apply to more situations than it would have without such adjudication.

The ability of judicial institutions to administer continuing international treaties gave them tremendous advantages over the piecemeal efforts of arbitral

93. Charles Evans Hughes, Possible Gains, 1927 Proc. SOC'Y AM. INT'L L. 1, 6 [hereinafter Hughes, Possible Gains].

94. Hughes, Institutions, supra note 88 , at 4 .

95. Id. 
panels, which only settled particular disputes. "It does not seem to be understood," he said, in reference to opponents of the Permanent Court,

that if we have an arbitration, the decision will depend upon the views of the umpire or a third arbitrator, and that if we cannot agree upon the selection of [him] the only way is to have him selected by some third Power... Many do not realize that a permanent court of international justice, with learned judges of approved character and independence ... . will afford a far more satisfactory recourse for us than the ordinary arbitral method. It is not realized that the establishment of a permanent court is in our own interest. ${ }^{96}$

The World Court offered the most efficient way of settling disputes arising under international treaties. ${ }^{97}$ Again, it is worthwhile to note Hughes' belief that the judicial form could take important issues out of politics. Arbitration required a new umpire for every specific dispute, and the parties would never agree upon that umpire. But if a World Court existed, then its judges would be impartial and apolitical because they operated in the world of law. ${ }^{98}$

\section{A Case Study: The Washington Naval Agreement of 1922}

Hughes did not hesitate to put his theoretical ideas into practice. His conception of international relations permeated the agreements arising out of the Washington Conference of 1922, which served as the hallmark of Republican foreign policy throughout the decade. ${ }^{99}$

The conference focused on questions of naval arms control and the territorial integrity of China. When it opened, few expected it to succeed, because no stable balance of power existed in the Far East and the United States, Britain, and Japan teetered on the brink of a full-blown naval arms race. ${ }^{100}$ Yet it did succeed, and largely due to Hughes. The "Washington

96. Hughes, Observations, supra note 79 , at 10.

97. Stimson noted that Hughes "thinks it is very important for us to have an opportunity to fall back upon the Court in the course of our diplomacy. It facilitates the solution of many troubles if we can say, 'All right, if we cannot agree, we will leave it to the World Court." "Memorandum of Conversation with Chief Justice Hughes on Monday, April 4, 1932," Stimson Diary, April 4, 1932.

98. Hughes argued that these problems with the arbitral method were the major reason why earlier arbitration treaties had not effectively regulated the international system. See HUGHES, PERMANENT COURT, supra note 85 , at 342 .

99. While space constraints prevent this Note from examining other areas in which Hughes put his ideas into practice, his conception of international relations was easily applicable to other areas of the world. For instance, Professor Smith observes that "[b]etween 1921 and 1933 [the United States] participated in 41 out of 44 conferences involving nations of the Western Hemisphere, in contrast to her participation in 23 out of 50 such conferences held between 1889 and 1921." Robert Freeman Smith, Republican Policy and the Pax Americana, 1921-1932, in FROM COLONY TO EMPIRE 253, 287 (William Appleman Williams ed., 1972).

100. The story of the Washington Conference has been told elsewhere effectively. See generally, e.g., Roger Dingman, POWER IN THE PACIFIC (1976). This Note only attempts to interpret the resuits of the Conference in light of the legal background of American foreign policy. In brief, the diplomatic background 
system"101 dominated the Far East for much of the decade; a naval armaments agreement was reached; and Hughes proudly announced the results as a vindication of his foreign policy. A close examination of the agreement reveals the scientific legal culture in action. But it also reveals its limitations.

\section{The Principles of Arms Control}

While the specific provisions of the Washington Conference Treaties are complex, the Conference's direction was settled on the first day with a dramatic speech by Hughes. Instead of reciting a boilerplate welcome, Hughes proposed to scrap hundreds of thousands of tons of naval vessels and freeze naval construction for the length of the treaty. The Secretary's plan hinged upon a strict ratio of capital ships between the United States, Britain, and Japan: the first two could have five tons for every three tons that Japan had. Despite some haggling over which ships could be kept and which had to be scrapped, the 5:5:3 ratio served as the core of the treaty.

Particularly revealing, though, is the way that Hughes later justified the ratio. The ratio's chief virtue derived not from the fact that with it, the United States could defend its vital interests, nor from the fact that it might have established an adequate balance of naval power; rather, he argued, the ratio succeeded because it was fair, and thus served as a suitable neutral principle upon which arms control could be balanced. "The question really comes," he asserted, "not to the advisability of such an agreement in the abstract, but to the fairness of a particular agreement." Rejoicing that the core value of the agreement lay in the fact that "[n]o unfair advantage is given to anyone," Hughes noted that instead of engaging in pointless arguments about national naval needs, he arrived at the 5:5:3 formula by taking the capital ship ratio that then existed. "What could be fairer than that?" he asked. ${ }^{102}$

Fairness was critical because this would create the consensus needed for a legally-regulated international system. Hughes argued that the naval agreement's most significant effect had not been establishing a stable balance but rather allaying the political tension between the contracting powers. The

was as follows. Before the First World War, the power of the Russian Empire and Imperial Germany in the Far East were matched by the Anglo-Japanese Alliance, creating a fairly stable balance of power in the area. The United States maintained a colony in the Philippines but lacked the naval power to play a major role in the area. Britain had by far the world's largest fleet, but the vast expanse of its possessions and competition from Germany put tremendous strategic and financial pressure upon it.

The First World War overthrew the old order. Russian power evaporated along with its imperial monarchy, and Germany was crushed by the Allies. This left the Anglo-Japanese alliance remaining with nothing to balance. The ensuing imbalance of power fed regional instability, and on the eve of the Conference, Britain, Japan, and the United States stood poised on the brink of a destabilizing arms race.

101. The phrase is Akira Iriye's. See AKIRA IRIYE, AFTER IMPERIALISM 20 (1965).

102. Hughes, Aspects, supra note 89 , at 45 . 
Conference "created a new atmosphere. The effect of the limitation ... was to give a practical assurance to each Power against invasion by the other."103

Similarly, he contended that "[t]he most important results are those which are unwritten and imponderable; those that relate to sentiment and purpose, to good will and a better understanding.... Quite apart from specific engagements, it was worth all the efforts of the Conference to produce a new state of mind with respect to our relations with the Far East."104 Arms limitation helped create a legally-regulated international system, for it hastened "the reign, let us say of reasonableness, if not of law-for, under that sway, law embodying right reason will develop fast enough ...."105 While conferences were not law, they created the conditions that built law. ${ }^{106}$

\section{Keeping Agreements}

The Conference's naval treaty was far from its only accomplishment. The questions of the Pacific security system remained unsolved as the conference began, and Hughes recognized the intimate connection between these questions and naval limitation. Any discussion of Far Eastern issues necessitated negotiations concerning China, where Japan saw itself as having special commercial and political rights, and where the United States insisted upon application of the Open Door principle.

The Open Door concept, which centered upon the idea of free trade in Asia, had played a key role in American diplomacy's publicly-stated values since Secretary of State John Hay's famous notes of 1899. While the Open Door held significance in the mind of American policymakers, however, it had no coherent meaning. Hay's China policy contained a central contradiction. His original notes tacitly accepted European spheres of influence in China by asking that within the European powers' spheres there be no interference with treaty ports, no extra tariffs on American goods, and no discriminatory railway rates or harbor dues. Yet the very next year, in the wake of the Boxer uprising,

103. Hughes, Possible Gains, supra note 93, at 11.

104. Hughes, Aspects, supra note 89, at 39-40. Root shared this view. See Stimson Diary, February $27,1922$.

105. Hughes, Possible Gains, supra note 93, at 7.

106. It should come as no surprise that Hughes applied the idea of international legal agreements as builders of peace when he focused on Europe. Two years later, in the wake of Ruhr Crisis (when France invaded Germany to gain reparations), and the ensuing financial settlement, he told the French Ambassador, Jules Jusserand, that he (Hughes) believed individual agreements could reinforce each other to create a more stable world order based upon law. The reparations settlement, Hughes contended, would create better feeling in Europe, which would in turn lead to more peaceful relations. Hughes saw this as backed by the evidence of history: the United States and Canada had previously had bitter relations and invaded each other's territory, he told Jusserand, but became amicable to the point where they maintained the world's longest unguarded border. Such a process of building harmony through the signing of arms-limitation agreements, said Hughes, was possible between France and Germany as well. Jusserand placated the Secretary, saying that he (Jusserand) would be "willing to have a similar arrangement on the condition that [the United States] would take the Germans and give the French the Canadians for their neighbors." "Memorandum of interview with French Ambassador, May 9, 1924," (Box 157, Hughes Papers). 
Hay called for a settlement that would preserve Chinese territorial integrity, which conflicted with the spheres of influence. ${ }^{107}$

At the Washington Conference, Hughes embraced the more expansive program of Hay's second set of notes. He was unwilling to grant Japan its sphere in China as Theodore Roosevelt had been: after all, this would be conceding to issues of power and interest that were antithetical to a legally-regulated international system. From the beginning, he felt that "the American policy in the Far East was one of equal opportunity," a position that was not only a policy but a "principle." ${ }^{108}$ In Hughes' mind, though, there existed a fatal weakness to the previous U.S. policy: its vagueness made it ineffective as means of inducing reciprocity and cooperation.

Thus, Hughes endeavored to make the Open Door formally realizable by transforming it from a general principle to a specific contract. Article III of the Nine-Power Treaty resulted from his labors. After making the usual bow to "equality of opportunity" in China, the Nine-Power Treaty stipulated that none of its signatories (except China itself) would seek, "a) any arrangement which might purport to establish in favor of their interests any general superiority of rights with respect to commercial or economic development in any designated region of China; b) any such monopoly or preference as would deprive the nationals of any other Power of the right of undertaking any legitimate trade or industry in China ... or which by reason of its scope, duration or geographical extent is calculated to frustrate the practical application of the principle of equal opportunity." 109

Article III made clear that Hughes favored the most expansive version of the Open Door. Japanese delegate Baron Shidehara protested as much, but Hughes countered by citing a 1909 agreement between then-Secretary of State Root and Japanese Ambassador Takahira, in which both Japan and the United States had pledged themselves to defend the principle of "equal opportunity for commerce and industry of all nations [in China]."110

Why, then, was a new treaty necessary? It was necessary because the Root-Takahira agreement was so vague as to be ineffective. Hughes argued that the new treaty advanced U.S. interests because the "postulates of American policy were taken out of the unsatisfactory form of diplomatic notes and, with a more adequate and explicit statement, were incorporated into a solemn international engagement, signed by the nine Powers especially interested in the Far East." ${ }^{\text {"11 }}$ Similarly, he contended that previous U.S.

107. See Raymond A. Esthus, The Open Door and the Integrity of China, 1899-1922: Hazy Principles for Changing Policy, in ASPECTS OF SINO-AMERICAN RELATIONS SINCE 1874, at 48-52 (Thomas H. Etzold ed., 1978).

108. Hughes, Aspects, supra note 89 , at 35 .

109. Article III of the treaty, quoted in GLAD, supra note 77, at 289.

110. See GLAD, supra note 77 , at 290 .

111. Charles Evans Hughes, The Monroe Doctrine-A Review: Its Relation to American Foreign Policy in the Twentieth Century, in THE PATHWAY OF PEACE, supra note 43, at 149 [hereinafter Hughes, Monroe 
policy concerning the Open Door had failed because it had never been "a matter of binding international obligation among all the powers concerned." ${ }^{\prime \prime 2}$ By casting the Far Eastern diplomatic question in the form of an international legal agreement, Hughes was able to put the various powers' reputations for fair dealing into the public arena, enhancing reciprocity and making their policies susceptible to judicial resolution. Underscoring Hughes' faith in the efficacy of law was the fact that the naval agreement had made it impossible for the United States to resist Japanese moves in China by force, because disarmament prevented the United States from fighting in the Pacific while also keeping its other naval commitments. But force, as Hughes saw it, was no longer necessary. As Beale had stated, there was either law or there was force, and since law existed in the Pacific, forcible methods were obsolete.

\section{CONCLUSION AND EPILOGUE}

In 1952, after he resigned his post as head of the State Department's Policy Planning Staff, George F. Kennan delivered a series of lectures that became a classic analysis of American foreign policy's travails during the twentieth century. In the lectures, Kennan castigated what he saw as the persistent "legalism" of American diplomacy. This legalism was not simply a practical failure on its own terms, but contained a "greater deficiency":

[T]he inevitable association of legalistic ideas with moralistic ones: the carrying-over into affairs of states of the concepts of right and wrong, the assumption that state behavior is a fit subject for moral judgment. Whoever says there is a law must of course be indignant against the lawbreaker and feel a moral superiority to him. ${ }^{113}$

Kennan was wrong. The legalism of Root and Hughes had many weaknesses, but moralism was not among them. The core of G.O.P. legal diplomacy lay not in its assertion of moral superiority, but in its advocates' conviction that they were propounding a logical response to international dilemmas. They saw their theory as buttressed by the facts of history. Individual nations had noncoercive legal orders; thus, the international community could have one as well. Indeed, the feasibility of their system rested upon their belief that all nations were rational and civilized.

Yet even though the diplomatic legalism of the 1920's was nonmoralistic and, by its own lights, a rational, hard-headed approach to global affairs, its intellectual foundations faced collapse even as it achieved its greatest

Doctrine]. Root also felt that the formality of the treaty was critical. See Letter from Root to Henry L. Stimson (October 2, 1925) (Stimson Papers).

112. Hughes' statement is contained in CONFERENCE ON THE LiMITATIONS OF ARMAMENTS, S. DOC. No. 126, 67th Cong., 2d Sess. 820 (1922), quoted in GLAD, supra note 77, at 299.

113. GEORGE F. KENNAN, AMERICAN DipLOMACY 1900-1950, at 100 (2nd ed. 1984). 
influence. Those in the legal realist movement saw the scientific legal culture's inherent instability. Law, the realists argued, rested upon coercion. ${ }^{114}$ Order existed not spontaneously but rather because a coercive state threatened retribution to those who would disobey. ${ }^{115}$ Society comprised many groups with sharply conflicting interests; thus, law could not be based upon natural social consensus. ${ }^{116}$ The question was not whether power existed, but whether a suitable balance of power existed in society. ${ }^{117}$ Thus, law could not be separated from politics. Legal decisions forced fundamental choices between competing groups and values. ${ }^{118}$ It thus made no sense to hope that neutral legal rules could ameliorate social conflict.

Many young lawyers took these lessons to heart. One of them was a Washington practitioner named Dean Acheson. Twenty years later, when Acheson became Secretary of State, he, too, remembered the lessons of the legal culture. But Acheson's legal culture centered upon the inevitable play of power in social life. And not surprisingly, American foreign policy during his tenure-a policy based upon containment-focused upon power as well. ${ }^{119}$

114. See, e.g., Morris R. Cohen, Property and Sovereignty, 13 CORNELl L.Q. 8, 12 (1927) ("The character of property as sovereign power compelling service and obedience may be obscured for us in a commercial economy by the fiction of the so-called labor contract as a free bargain . ...").

115. See, e.g., OLIVER WENDELl HOLMES, The Path of the Law, in COLleCTEd LeGAL PAPERS 167, 175 (1920) (arguing that "[t]he duty to keep a contract at common law means a prediction that you must pay damages if you do not keep it-and nothing else.").

116. It should be obvious that $I$ am suggesting that the connections between legal realism and foreign policy realism are not merely a matter of linguistic fortuity. Holmes-considered the earliest of the legal realists-expressed the belief in the permanence of power as early as 1880:

[T] he ultima ratio, not only regum, but of private persons, is force, and . . . at the bottom of all private relations, however tempered by sympathy and all the social feelings, is a justifiable self-preference. If a man is on a plank in the deep sea which will only float one, and a stranger lays hold of it, he will thrust him off if he can. When the state finds itself in a similar position, it does the same thing.

Oliver Wendell holmes, The Common LaW 38 (Mark D. Howe ed., Bantam Books 1975) (1880). Compare HaNS J. MORGENTHAU, POLITICS AMONG NATIONS 30-31 (4th ed. 1957) ("[T] he struggle for power is universal in time and space and is an undeniable fact of experience.").

117. See, e.g., Robert L. Hale, Coercion and Distribution in a Supposedly Non-Coercive State, 38 PoL. SCI. Q. 470 (1923).

118. See, e.g., Cohen, supra note 114, at 13 (arguing that "the ownership of land and machinery ... determines the future distribution of the goods that will come into being-determines what share of such goods various individuals shall acquire."); see also id. at 14 (noting "ways in which the wealthy few determine the mode of life of the many ..." ).

119. See generally DEAN ACHESON, PRESENT at the CREATION: MY Years in the State DEPARTMENT (1969). 